$$
\begin{array}{cccc}
\text { S sciendo } & \text { International Conference KNOWLEDGE-BASED ORGANIZATION } \\
\text { Vol. XXVII } & \text { No } 1 & 2021
\end{array}
$$

\title{
QUANTIFICATION OF THE SUSTAINABLE USE OF THE CULTURAL HERITAGE IN THE CENTRAL AREA OF THE MUNICIPALITY OF PLOIEŞTI USING THE COBACHREM MODEL
}

\author{
Florentina-Cristina MERCIU, George-Laurenţiu MERCIU, Loreta CERCLEUX \\ University of Bucharest, Romania \\ cristina.merciu@geo.unibuc.ro, george.merciu@geo.unibuc.ro, \\ loreta.cercleux@geo.unibuc.ro
}

\begin{abstract}
Making connections between the localization of cultural heritage elements and local and regional policies for the benefit of communities, at different scales, has been one of the constant concerns of researchers and policy makers. The purpose of this study is to highlight the effects generated by cultural policy at the local, regional and central level, through investments allocated to cultural heritage in the central area of Ploieşti. The local policy aimed at building a more attractive image of Ploieşti through the renovation of the most important cultural institutions, benefiting from the funds allocated by the administration at regional and central level and European funds. The analysis of the effects produced by the investments related to the historical monuments from the central area of Ploieşti municipality was carried out through the Community-Based Cultural Heritage Resources Management (COBACHREM) model.
\end{abstract}

Keywords: urban heritage, cultural policy, conservation, economic value, quality of life

\section{Introduction}

The definition of policies for capitalizing on cultural heritage must be correlated with its sustainable use, especially in the current context marked by accelerated urban development. The protection of cultural heritage is seen as a limitation of urban development [1,2]. Policy makers are interested in having estimates of the effects of investment in cultural heritage on the local and regional economy. Building development models and defining specific policies will focus on how current decisionmakers shape the most appropriate types of governance.

This study aims to analyze the effects generated by cultural policy at local, regional and central level, focusing on the multiplier character and the acceleration of the investment allocated to the cultural heritage, materialized in the form of conservation and reuse of the heritage buildings. For the most complex highlighting of the ways of analysis and capitalization of the cultural heritage, one of the most complex models currently used for this purpose was selected, namely: Community-Based Cultural Heritage Resources Management (COBACHREM). The selected case study is the central area of Ploieşti Municipality, which, although it has lost historical buildings over time [3], it concentrates within its limits a variety of historical monuments valued from a cultural point of view, representing symbols of history and local culture.

\section{Methodology}

The application of the COBACHREM model allows the quantification of the 
degree of sustainable capitalization of the elements of cultural heritage located in a certain territory (at local level) [4]. The application of this model consists of two stages:

- stage 1 includes: complex analysis of the characteristics of the cultural product (level I: inputs, production); identification of the main stakeholders that manage the patrimony elements (level II: the reproduction analyzed from the perspective of the catalytic and regenerative agents, respectively of the elements that produce changes related to the use of the patrimony elements); analysis of the use of heritage elements by the local population and tourists (level III: consumption).

- the second stage involves the monitoring of the elements of cultural heritage (level IV), depending on the data obtained in the first stage, from the perspective of sustainable capitalization; at this stage, cultural conservation indicators are identified for each level.

Thus, synthetically, the general scheme of the COBACHREM model is the following (table 1):

Table 1: COBACHREM Model Matrix

\begin{tabular}{|c|c|c|}
\hline STAGE 1 & & \\
\hline $\begin{array}{l}\text { Level I Inputs } \\
\text { (Production) }\end{array}$ & $\begin{array}{l}\text { Level II Catalytic and } \\
\text { regenerative agents } \\
\text { (Reproduction) }\end{array}$ & $\begin{array}{l}\text { Level III Outputs } \\
\text { (Consumption) }\end{array}$ \\
\hline \multirow{4}{*}{$\begin{array}{l}\text { Tangible heritage } \\
\text { Historical monuments } \\
\text { Cultural institutions } \\
\text { Cultural landscape } \\
\text { Nontangible heritage } \\
\text { Performing arts } \\
\text { Festivals } \\
\text { Social practices }\end{array}$} & $\begin{array}{l}\text { Local organization / Community } \\
\text { Community groups } \\
\text { NGOs }\end{array}$ & \multirow{4}{*}{$\begin{array}{l}\text { Interpretation and } \\
\text { research } \\
\text { Forms of identity and } \\
\text { claims } \\
\text { Conservation at local } \\
\text { level } \\
\text { Forms of commercial } \\
\text { capitalization (tourism) }\end{array}$} \\
\hline & $\begin{array}{l}\text { Administrative-territorial unit } \\
\text { Policies } \\
\text { NGOs }\end{array}$ & \\
\hline & Regional and central level & \\
\hline & $\begin{array}{l}\text { International level (UNESCO) } \\
\text { International Conventions }\end{array}$ & \\
\hline \multicolumn{3}{|l|}{ STAGE 2} \\
\hline \multicolumn{3}{|c|}{ Level IV } \\
\hline $\begin{array}{l}\text { Production indicators: } \\
\text { - access and use parameters }\end{array}$ & $\begin{array}{l}\text { Reproduction indicators: } \\
\text { - socio-spatial indicators } \\
\text { - socio-political indicators } \\
\text { - socio-economic indicators } \\
\text { - catalysts for cultural change }\end{array}$ & $\begin{array}{l}\text { Consumption } \\
\text { indicators: } \\
\text { - socio-spatial indicators } \\
\text { - heritage interpretation } \\
\text { parameters (internal / } \\
\text { external) }\end{array}$ \\
\hline
\end{tabular}

Source: [4], pg. 75, with modifications adapted to the case study

\section{Results}

The municipality of Ploieşti represents a particular case study, as a result of the evolution registered by the historical monuments marked by destructions during the Second World War or during the 
communist period [3]. The municipality also owns a number of historic buildings that are categorized at seismic risk [5] and that require consolidation interventions.

In recent years, the local public administration has implemented actions to reposition the municipality in the cultural competition at the national level, by protecting the historical buildings and by revitalizing the traditions of theater, poetry, to create an improved cultural image of the municipality [6]. This measure is related to the capitalization of the cultural heritage achieved by renovating some historical buildings that are the headquarters of some important cultural institutions ("Paul Constantinescu" Memorial Museum, Palace of Culture, Clock Museum) [7].

The application of the COBACHREM model supposed in a first stage the inventory of the elements of material and intangible patrimony (level I: production). The municipality of Ploiesti presents a varied typology of cultural heritage elements, including monuments of architectural value (cultural institutions, museums, churches, residential buildings), industrial buildings (e.g. Central Market Hall - the current main market of the city). The category of intangible heritage elements includes the organization of festivals, some with an international character, which attract participants from both tourists and the local population: the International Film Festival (PIFF), the International Jazz Festival "Ploieşti Hot Jazz Summit", "Toma Caragiu" Theater Festival, "Paul Constantinescu" International Interpretation and Artistic Creation Contest, etc.

The analysis of the catalytic and regenerative agents for the study area allowed the identification, on the one hand, of the members of the local community, grouped in owners' associations, who are preoccupied with the consolidation of the residential buildings categorized at seismic risk. In Ploieşti, the League of Owners Associations "Habitat" was established, which organizes debates on topics of interest (condominium administration, evaluation and monitoring of public utilities, compulsory housing insurance) in which representatives of owners' associations and operators in the field can participate (water administration, energy, town hall, local council) (table 2).

On the other hand, there is a relatively large number of NGOs (Cultural Association Essence of Knowledge, ATOM Association, etc.) that advocate for the preservation of historical buildings, promoting the cultural heritage of the municipality through various publications: books (ATOM Association), the first bilingual tourist map of the city elaborated by the "I Love Ploieşti" Association. Other NGOs related to culture are dedicated to promoting Romanian culture and art, supporting originality in artistic creation (ECHINOX Cultural-Artistic Association), promoting contemporary art by organizing artistic activities (concerts), forming an orchestra and stimulating interest in culture among pupils and students for personal development (MOMENTUM Association), supporting cultural activity in Ploieşti, Prahova County and at the national level ("Paul Constantinescu" Cultural Association).

The central authority, the Ministry of Culture, started, since 2000, the decentralization activity, which allowed through affiliated institutions to carry out actions related to the listing of historical monuments, updating the list, as well as actions to preserve the national cultural heritage [8], even if the fund allocated for conservation is still low. One of the institutions in the structure of the Ministry of Culture is the Administration of the National Cultural Fund, which has the role of financing projects that support contemporary Romanian creation and heritage capitalization, which contributes to the widest possible access to culture for the public. 
Regarding the degree of capitalization (consumption) of heritage buildings in the studied area, the diversity of reuses of historical buildings is observed, especially commercial, tourist and cultural services, which reflects the influence of tourism on the ways of reuse of historical buildings (table 2). The cultural reuse of some heritage buildings is noticeable: the house where the musician Paul Constantinescu lived and created, transformed since 1993 into a memorial museum that also hosts various cultural-artistic manifestations.

In the second stage of the study, the monitoring of the cultural heritage elements was carried out and indicators were selected that reflect the degree of conservation and capitalization of the historical buildings.

As indicators of production were selected: the degree of accessibility calculated based on the routes of public transportation; the central area of the municipality is characterized by a high degree of accessibility, being served by several means of public transportation; the central area is located very close to the main train station, being easily accessible to tourists.

The second indicator selected was the number of historical monuments classified at seismic risk. In the study area there are 5 buildings classified at seismic risk grade 1 and 5 buildings at seismic risk grade 2 .

From the reproduction indicators were selected: socio-spatial indicators: number of renovated historical monuments: the following buildings have been renovated in recent years: Clock Museum, "Paul Constantinescu" Memorial Museum, and Palace of Culture.

From the category of socio-political indicators, the indicator that was selected: the share of public funds allocated for the restoration of historical monuments: for example, for the restoration of the Memorial Museum "Paul Constantinescu", $15 \%$ of the investment value was allocated from the national budget, most being provided from the EEA Grants. For the Clock Museum, most of the restoration funds were allocated from European funds.

The main elements that have contributed to cultural changes are the investments for cultural and tourist uses of the cultural institutions mentioned above, to which are added the private investments for commercial and tourist reuses of some heritage buildings in the central area of the municipality. As a socio-economic indicator, the following were selected: the number of culturally reused historical monuments: their number is relatively small, the most important heritage buildings being used as museums. Although most of the heritage properties from the central area of Ploieşti Municipality are used as dwellings, several cultural monuments have commercial function or they are reused as hotels and restaurants. 
Table 2 Application of the COBACHREM Model for evaluating the ways of capitalizing on the cultural heritage in the central area of Ploieşti Municipality

\begin{tabular}{|c|c|c|}
\hline STAGE 1 & & \\
\hline Level I Inputs (Production) & $\begin{array}{c}\text { Level II Catalytic and regenerative } \\
\text { agents (Reproduction) }\end{array}$ & $\begin{array}{l}\text { Level III Outputs } \\
\text { (Consumption) }\end{array}$ \\
\hline \multirow{4}{*}{$\begin{array}{l}\text { Tangible heritage } \\
\text { Historical monuments: Clock } \\
\text { Museum } \\
\text { Cultural institutions: Palace of } \\
\text { Culture } \\
\text { Nontangible heritage } \\
\text { Festivals: International Film } \\
\text { Festival (PIFF); } \\
\text { "Toma Caragiu" Theater } \\
\text { Festival } \\
\text { Social practices: } \\
\text { cultural education, cultural } \\
\text { management and marketing } \\
\text { practices } \\
\text { for the promotion of } \\
\text { Romanian culture and art, } \\
\text { supporting originality in } \\
\text { artistic creation }\end{array}$} & $\begin{array}{l}\text { Local organization / Community } \\
\text { Community groups: owners' } \\
\text { associations vs. consolidation of } \\
\text { residential buildings } \\
\text { NGOs: } 9 \text { NGOs focused on heritage } \\
\text { conservation, cultural education }\end{array}$ & \multirow{4}{*}{$\begin{array}{l}\text { Interpretation and research } \\
\text { Local conservation: } \\
\text { consolidation of historic } \\
\text { buildings classified at } \\
\text { seismic risk } \\
\text { Forms of economic } \\
\text { capitalization: } \\
\text { tourism, commercial } \\
\text { activities, cultural uses of } \\
\text { historical buildings: } \\
\text { museums (Paul } \\
\text { Constantinescu Memorial } \\
\text { Museum), art galleries, etc. }\end{array}$} \\
\hline & $\begin{array}{l}\text { Administrative-territorial unit } \\
\text { City Development Strategy (2007- } \\
2025) \\
\text { Integrated urban development strategy } \\
\text { of the municipality (2014-2020) }\end{array}$ & \\
\hline & $\begin{array}{l}\text { Regional and central level } \\
\text { Ministry of Culture and affiliated } \\
\text { institutions: National Cultural Fund } \\
\text { Administration (AFCN) } \\
\text { National Cultural Strategy (2016- } \\
\text { 2022) }\end{array}$ & \\
\hline & $\begin{array}{l}\text { International level (UNESCO) } \\
\text { International Conventions (UNESCO } \\
1972,2003)\end{array}$ & \\
\hline \multicolumn{3}{|l|}{ STAGE 2} \\
\hline \multicolumn{3}{|c|}{ Level IV } \\
\hline $\begin{array}{l}\text { Production indicators: } \\
\text { - access and use parameters: } \\
\text { - the degree of accessibility } \\
\text { through the use of public } \\
\text { transportation; } \\
\text { - the number of historical } \\
\text { monuments classified at } \\
\text { seismic risk. }\end{array}$ & $\begin{array}{l}\text { Reproduction indicators: } \\
\text { - socio-spatial indicators: number of } \\
\text { consolidated historical monuments, } \\
\text { number of renovated historical } \\
\text { monuments } \\
\text { - socio-political indicators: } \\
\text { the share of public funds allocated for } \\
\text { the restoration of historical } \\
\text { monuments } \\
\text { - catalysts for cultural change: } \\
\text { investments for tourist and commercial } \\
\text { uses, urban regeneration projects } \\
\text { - socio-economic indicators: the } \\
\text { number of culturally reused historical } \\
\text { monuments }\end{array}$ & $\begin{array}{l}\text { Consumption indicators: } \\
\text { - socio-spatial indicators: } \\
\text { - the share of the resident } \\
\text { population involved in the } \\
\text { conservation of historical } \\
\text { monuments; } \\
\text { - the share of the resident } \\
\text { population participating in } \\
\text { cultural activities; } \\
\text { - heritage interpretation } \\
\text { parameters (internal / } \\
\text { external): } \\
\text { - the number of historical } \\
\text { monuments improperly } \\
\text { reused }\end{array}$ \\
\hline
\end{tabular}

Source: elaborated by Merciu F. C.

The evaluation of consumption was made based on the analysis of the share of the resident population involved in the conservation of historical monuments and the share of the resident population participating in cultural activities, both 
indicators registering high values.

There is a concern of the resident population in the action of consolidation / renovation of cultural buildings in the central area of the municipality, due to the large stock of old buildings that are represented by both housing and cultural objectives.

The indicator of the number of improperly reused historical monuments reflects the situation of commercial buildings that have been improperly renovated (e.g. the use of non-compliant materials: insulated windows).

\section{Conclusions}

The application of the COBACHREM model allowed the quantitative and qualitative evaluation of the measures for the conservation and capitalization of the cultural heritage from the central area of Ploieşti municipality. It also stands out a strong impact of cultural heritage conservation on the quality of life of the local population.

\section{Acknowledgements}

This work was supported by the research project: "Complex multidisciplinary platform for integrative and systemic research of identities and tangible and nontangible cultural heritage in Romania" UEFISCDI project no. PN-III-P1-1.2PCCDI-2017-0686.

\section{References List}

[1] Fairclough G., Harrison R., Jameson J.H.J. The heritage reader. London: Routledge; 2008.

[2] Pendlebury J.R. Conservation in the age of consensus. 1st edition. London: Routledge; 2008.

[3] Merciu F.C., Ianoş I., Cercleux A.L., Merciu G.L. Evaluation of the economic values of urban heritage in the central area of Ploieşti municipality. Proceeding of the International Conference Knowledge Based Organization. 2020; 26 (2): 58-62.

[4] Keitumetse S. O. Cultural resources as sustainability enablers: towards a communitybased cultural heritage resources management (COBACHREM) model. Sustainability. 2014; 6: 70-85.

[5] Ploieşti City Hall, list of buildings with seismic risk [Internet]. Ploiesti; 2016 [accessed: 18.01.2021]. Available from: http://www.ploiesti.ro/blocuri\%20risc.pdf

[6] IHS Romania SRL. Development strategy of Ploieşti municipality 2007-2025 [Internet]. Ploiești: Ploiești City Hall; 2007 [accessed: 20.02.2021]. Available from: http://www.ploiesti.ro/ploiesti_document.pdf

[7] Ploieşti City Hall. Integrated Urban Development Plan of the Ploieşti-Prahova Growth Pole, part 4 a: Action Plan [Internet]. Ploieşti: Ploieşti City Hall. 2009: Ploieşti [accessed: 28.02.2021]. Available from: http://www.ploiesti.ro/pidu032010/partea\%204_cz\%20\%20rev.pdf

[8] Ministry of Culture. Strategy for culture and national heritage 2016-2022 [Internet]. Bucharest: Ministry of Culture; 2016 [accessed: 01.03.2021]. Available from: http://www.cultura.ro/sites/default/files/inline-files/_SCPN\%202016-2022inavizare.pdf 